\title{
PENERAPAN METODE 5R (RINGKAS, RAPI, RESIK, RAWAT, RAJIN) DAN IDENTIFIKASI POTENSI BAHAYA DI GUDANG BAHAN KIMIA LABORATORIUM MIPA
}

\author{
Riana Septiani, Mirandi Pratiwi \\ Program Studi Teknik Industri Fakultas Teknik \\ Universitas Tulang Bawang Lampung
}

\begin{abstract}
This research is about Application of $5 R$ methods ((Ringkas, Rapi, Resik, Rawat, Rajin) and indentification of hazard potential in Chemical Warehouse. And it aims to improve the work environment in the laboratory by using the $5 R$ work method and identify potential hazards contained.

Analysis of the two problems was carried out using several methods, namely for the implementation of warehouse layout with the $5 R$ method, and for work safety using hazard identification \& risk assessment using Pareto Chart Analysis to discuss the level of work accident risk from the highest to the lowest, and proceed by using a Fishbone Chart Analysis to analyze the types of work accidents from the factors that cause the risk of accidents.

The index value before the application of $5 R$ has a value of $20 \%$, while the index value after improvement is $75.6 \%$ and the result of hazard identification has 23 hazard risks from 7 activities with an area that has a very high level of hazard risk.
\end{abstract}

Keywords: 5R, occupational safety, hazard identification, risk assessment, work accidents, Chemical Warehouse

\section{Pendahuluan}

Keberadaan laboratorium berperan dalam kemajuan lembaga pendidikan. Banyak kecelakaan laboratorium berupa kebakaran, peledakan atau kebocoran bahan kimia beracun dan korosif yang dimulai dari tempat penyimpanan bahan.Ini dapat terjadi akibat penyimpanan bahan yang kurang aman, baik ditinjau dari ruang penyimpanan maupun sistem penataan bahan. Letak gudang yang terpencil, menyebabkan jarang diadakan inspeksi sehingga adanya kondisi berbahaya dalam gudang terlambat untuk dapat diketahui.Penyimpanan bahan kimia dalam jenis dan jumlah yang banyak memerlukan pengetahuan akan syaratsyarat penyimpanan. Kecelakaan dalam gudang kimia dapat menimbulkan cedera bahkan kematian, selain kehilangan bahan kimia yang mahal.

Faktor utama dari kenyamanan kerja adalah keselamatan kerja, khususnya terkait dengan kecelakaan kerja. Kecelakaan bukanlah suatu peristiwa tunggal melainkan dari serangkaian penyebab yang saling berkaitan yang disebakan oleh kelemahan majikan, pekerja, prosedur kerja yang tidak memadai, serta tindakan para pekerja yang tidak aman. Salah satu cara untuk mencegah kecelakaan kerja di tempat 
kerja adalah dengan menetapkan dan menyusun prosedur pekerjaan dan melatih semua pekerja untuk menetapkan metode kerja yang efisien dan aman.
Pada Tabel 1 dapat dilihat data kecelakaan kerja dari tahun 2015 - 2018 sebagai berikut:

Tabel 1. Data Kecelakaan di Gudang Bahan Kimia Laboratorium MIPA dari tahum 2015-2018

\begin{tabular}{|c|c|c|c|c|}
\hline No & Tahun & $\begin{array}{c}\text { Jumlah } \\
\text { Kecelakaan }\end{array}$ & Jenis Kecelakaan & Tota1Kejadian \\
\hline \multirow[t]{4}{*}{1} & 2015 & $8 \mathrm{kali}$ & Keturn pahan bahan kimia & 16 \\
\hline & & 4 kali & Terpeleset & \\
\hline & & 2 kali & Terjadiledakan & \\
\hline & & 2 kali & Terbakar & \\
\hline \multirow[t]{3}{*}{2 . } & 2016 & 5 kali & $\begin{array}{l}\text { Kesalahan pengambilan } \\
\text { bahan }\end{array}$ & 13 \\
\hline & & $4 \mathrm{kali}$ & Terbiture & \\
\hline & & 4 kali & Terpeleset & \\
\hline \multirow[t]{2}{*}{3.} & 2017 & $4 \mathrm{kali}$ & $\begin{array}{l}\text { Kesalahan pengambilan } \\
\text { bahan }\end{array}$ & 11 \\
\hline & & 7 kali & Ketum pahan bahan kimia & \\
\hline \multirow[t]{5}{*}{4.} & 2018 & $6 \mathrm{kali}$ & Terbitule & 10 \\
\hline & & 3 kali & Ketum pahan bahan kimia & \\
\hline & & 1 kali & Teriadiledakan & \\
\hline & \multicolumn{3}{|c|}{ TOTAL } & 50 \\
\hline & $\tilde{E}$ & : & Data & \\
\hline
\end{tabular}

Penelitian ini bertujuan untuk memperbaiki lingkungan kerja pada laboratorium dengan menggunakan metode kerja 5R serta mengidentifikasi potensi bahaya yang terdapat pada gudang bahan kimia di laboratorium MIPA.

\section{Tinjauan Pustaka \\ GudangBahan Kimia}

Menurut Warman (2012), gudang adalah bangunan yang digunakan untuk menyimpan barang, dapat berupa bahan baku, barang setengah jadi, suku cadang, atau barang dalam proses yang disiapkan untuk diserap oleh proses produksi. Sistem pergudangan yang baik adalah sistem pergudangan yang mampu memanfaatkan ruang besar ataupun kecil untuk penyimpanan barang-barang secara efektif dan efisien agar dapat meningkatkan produktivitas barang yang ada di perusahaan, jika gudang dalam keadaan baik maka sistem pergudangan akan selalu berjalan dengan lancar.

Gudang bahan kimia merupakan aset yang harus dijaga keselamatan dan keamanannya karena tersimpan berbagai bahan kimia yang memiliki sifat yang berlainan. Beberapa diantaranya berbahaya seperti bahan mudah terbakar, mudah meledak, beracun dan korosif. Ada juga bahan kimia yang bersifat "biasabiasa" saja, namun dapat dijadikan bahan baku dalam pembuatan bahan kimia baru yang berpotensi mencelakakan mahluk hidup dan lingkungan. Kecelakaan berupa kebakaran, ledakan akibat interaksi bahan kimia atau faktor lainnya sudah sering terjadi. Dengan mengatur kondisi gudang dan menata sistim penyimpanan bahan 
kimia sesuai dengan sifatnya, maka halhal tersebut dapat dicegah dan perlu pula perencanaan tindakan (antisipasi) jika kecelakaan tetap terjadi. Patut pula dipahami upaya penanggulangannya dan mengurangi akibat yang ditimbulkannya.

Fungsi gudang zat kimia di perusahaan pada umumnya sama dengan gudang lainnya, yaitu sebagai tempat penyimpanan barang dan alat-alat kerja. Bahan-bahan kimia dan peralatan yang akan digunakan untuk kegiatan operasional di lapangan. Aktivitas yang dilakukan harus mengikuti prosedur prosedur yang berlaku dan karyawan gudang harus melakukan penyimpanan barang sesuai dengan jenis serta spesifikasi masing-masing barang tersebut, sehingga dapat mempermudah saat pengambilan dan pengeluaran barang dan menghemat waktu dalam melakukan pencarian barang yang dibutuhkan (Hutahaean, H. H. 2006).

Berdasarkan pengamatan langsung di gudang zat kimia, terdapat permasalahan mengenai penataan dan perawatan yang kurang optimal, yakni ada beberapa barang yang kondisi tata letaknya masih kurang rapi atau berantakan, sampah, kotoran serangga dan debu di mana-mana (Gasperz, V. 2012).

Perawatan dan penataan gudang perlu menerapkan prinsip 5R untuk mengoptimalkan permasalahan di dalam gudang zat kimia tersebut. Melalui prinsip 5S/5R gudang akan menghasilkan jasa layanan dan produk yang berkualitas bagi konsumen (Imai, M. 1986). Penerapan prinsip 5R sendiri sudah sering dilakukan dan terbukti efektif untuk memperbaiki produktivitas kerja, seperti di lantai produksi (Nugraha, A.S., Desrianty, A., \& Irianti, L. 2015).

\section{Pengertian 5R}

Guna menciptakan budaya kerja dan budaya perusahaan yang baik, maka diperlukan banyak usaha untuk mencapainya. Perusahaan melaksanakan MESH System (Management, Environment, Safety, and Health System) sebagai wujud kesadaran akan pentingnya keadaan lingkungan kerja, kesehatan dan keselamatan kerja. Salah satu cara untuk mengimplementasikan MESH System adalah dengan melakukan penerapan housekeeping management dari Jepang, yaitu: 5S yang terdiri dari Seiri, Seiton, Seiso, Seiketsu dan Shitsuke. Sedangkan bila di artikan ke dalam bahasa Indonesia menjadi 5R yaitu: Ringkas, Rapi, Resik, Rawat dan Rajin. Melalui penerapan program 5S/5R diharapkan berbagai pemborosan yang ada dapat diminimalkan sehingga terjadi peningkatan produktifitas dan efektivitas dari perusahaan (Osada, 2011).Menurut Suwarni P Endah (2019) padaproduktivitas UMKM jenis makanan ada terjadi peningkatan setelah penerapan 5R sebesar $20 \%$.

Penjelasan 5R dapat dijelaskan sebagai berikut

\section{a. Ringkas}

Secara konsep, "Ringkas" disini dijelaskan sebagai tindakan untuk menyimpan barang yang dibutuhkan atau bisa dikatakan untuk menyingkirkan barang yang tidak perlu. Kenyataannya ketika kita meringkas barang yang tidak dibutuhkan timbul alasan-alasan yaitu membuang barang itu pemborosan dan membutuhkan waktu atau mungkin kita suatu saat pasti menggunakannya. Jalan terbaik untuk mengakhiri konflik itu adalah pemilihan yang jelas tentang barang yang diperlukan atau tidak (Frans M Royan, 2009: 274). Kegiatan "Ringkas" yang efektif akan menciptakan perasaan akan ruang yang lebih lega karena hanya barang - barang yang diperlukan saja yang tinggal, sehingga pekerja merasa nyaman dan lebih leluasa dalam menjalankan pekerjaan mereka (SIEN Konsultan, 2012: $5)$.

b. Rapi

Konsep ini mengajarkan untuk menyimpan atau meletakkan barang di tempat penyimpanan barang yang sudah disediakan. Berikan tanda visual di setiap barang dan tempat penyimpanan dengan cara memberikan label. Meletakkan barang 
sesuai dengan tingkat frekuensi pemakaiannya dan pastikan semua orang yang ingin menggunakannya mengerti maksud dan tujuan dari penempelan label pada barang atau tempat penyimpanan. Tujuannya agar barang dapat dilihat, dapat dikeluarkan, dan mudah untuk dikembalikan. Yang terpenting dari konsep "Rapi" ini adalah barang diletakkan dalam posisi yang tetap, tidak mudah berubahubah dan jumlah yang ditata dalam bentuk tetap pula. Konsep "Rapi" yang efektif akan mengurangi pemborosan waktu pencarian barang dan meningkatkan produktifitas (SIEN Konsultan, 2012: 5, Frans M. Royan, 2009: 274).

\section{c. Resik \\ Konsep "resik" pada intinya} menekankan pada tindakan untuk membersihkan lingkungan kerja yang dilakukan oleh setiap karyawan secara individu atau bersama-sama. Aktifitas resik ini akan mengakibatkan area kerja menjadi lebih nyaman dan menunjukkan alat dalam keadaan baik dan siap pakai (SIEN Konsultan, 2012: 5, Frans M. Royan 2009: 274-275).

d. Rawat

Konsep rawat ini merupakan proses untuk mempertahankan standar yang sistemik untuk memastikan tiga konsep yaitu Ringkas, Rapi, Resik dapat dipelihara agar setiap penyimpangan dan ketidaknormalan menjadi lebih mudah untuk ditangani atau dikendalikan. Konsep ini juga dapat diaplikasikan dengan cara memasang media informasi atau peraturan di area keja. Selain itu, juga bisa dilakukan dengan cara mememberikan reward (bonus atau penghargaan) kepada pelaksana maupun yang bertanggung jawab terhadap wilayah penataan barang. Dengan konsep ini, para konsumen juga akan merasa nyaman dengan lingkungan perusahaan saat akan menggunakan jasa atau membeli produk perusahaan (SIEN Konsultan, 2012: 6, Frans M. Royan 2009: 275, Jeffrey K. Liker, 2005: 182).

d. Rajin
Tindakan yang terakhir dari metode 5R ini adalah mekanisme untuk memantau pencapaian 4 konsep sebelumnya, memastikan setiap karyawan menjalankan seluruh aktifitas 5R secara disiplin. Pemeriksaan secara teratur/rajin pada kegiatan 5R ini dapat dilakukan dengan menggunakan patrol 5R setiap hari, setiap minggu atau minimal sebulan sekali, Papan informasi 5R, Pertemuan 5 menit di lapangan dan cheklist 5R.

\section{Identifikasi Bahaya}

Hazard adalah aktivitas,obyek, komponen yang dianggap dapat menimbulkan kerusakan atau terganggunya proses/aktivitas didalamnya hingga kecelakaan kerja(Cooling,1990). Hazard Identification (HIRA) adalah suatu metode pengukuran/penentuan resiko dari hazard sehingga dapat diprediksi tingkat resiko dan impact dari hazard yang ada(Labovsky,J, 2006 ). Terdapat empat tahap dalam HIRA yakni (Keltz, 2003): Hazard Identification(HAZID) merupakan sebuah proses identifikasi hazards sebagai langkah awal penentuan analisis resiko. Terdapat dua tujuan utama dalam identifikasi hazard yakni untuk mendapatkan daftar hazard dan urutannya berdasarkan tingkat resiko serta untuk mendapatkan penilaian kualitatif hazards dan cara untuk mengurangi tingkat resiko hazard. Penentuan Resiko (Risk Assessment). Pada tahapan ini setiap hazard yang telah diidentifikasi ditentukan nilai resikonya. Tingkat resiko dilihat dari efek/impact hazard terhadap pegawai, lingkungan kerja secara khusus dan umum apabila memungkinkan. Analisis Resiko (Risk Analysis) merupakan tahapan selanjutnya dalam analisa identifikasi hazard. Pada tahapan ini dilakukan analisa dan penentuan rangking dari hazard berdasarkan informasi yang ada. Penentuan skala prioritas penanganan dilakukan berdasarkan penentuan rangking analisis resiko hazard. 
Identifikasi Bahaya, Penilaian Resiko dan Pengendalian Resiko merupakan salah satu syarat elemen Sistem Manajemen Keselamatan Kerja OHSAS 18001:2007 klausul 4.3.1. OHSAS atau singkatan dari Occupational Health and Safety Assessment Series (OHSAS 18001) adalah suatu standard internasional untuk menerapkan Sistem Manajemen Keselamatan dan Kesehatan Kerja di tempat kerja/ perusahaan. Banyak organisasi di berbagai Negara telah mengadopsi OHSAS 18001 untuk mendorong penerapan keselamatan dan kesehatan kerja dengan melaksanakan prosedur yang mengharuskan organisasi secara konsisten mengidentifikasi dan mengendalikan resiko bahaya terhadap keselamatan dan kesehatan di tempat kerja; serta memperbaiki kinerja dan citra perusahaan.

OHSAS 18001 diterbitkan pada tahun 1999 dan diperbaharui pada tahun 2007 yaitu tanggal 1 Juli 2007 sebagai tanggapan atas permintaan organisasi yang memiliki spesifikasi Sistem Manajemen Keselamatan dan Kesehatan Kerja. OHSAS 18001 memberikan persyaratan suatu organisasi untuk mengontrol kesehatan dan risiko keselamatan di tempat kerja dan meningkatkan kinerja mereka. Namun OHSAS 18001 tidak menetapkan kriteria kinerja spesifik, dan memberikan spesifikasi rinci untuk desain sistem manajemen. Identifikasi Bahaya dilaksanakan guna menentukan rencana penerapan K3 di lingkungan Perusahaan.

Berikut adalah Lingkaran Identifikasi Bahaya.

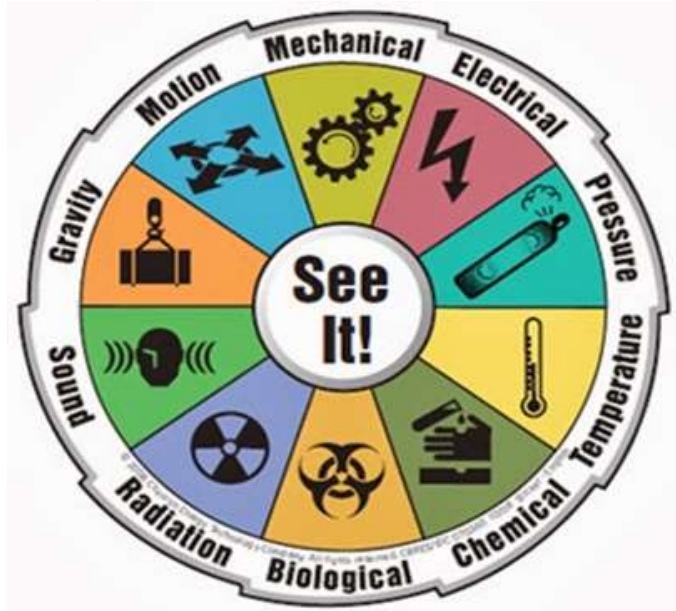

Gambar 1. Lingkaran Identifikasi Bahaya

Sumber: Wahyudi B. Agung (BAB 2 Identifikasi Bahaya)

Form Identifikasi Bahaya

Form Identifikasi Bahaya,

Penilaian dan Pengendalian Resiko digunakan untuk mengidentifikasi semua potensi bahaya $\mathrm{K} 3$ yang terdapat di dalam aktivitas-aktivitas Organisasi/Perusahaan di tempat kerja, dilanjutkan dengan melakukan penilaian resiko dari potensi bahaya tersebut serta menentukan langkahlangkah pengendalian bahaya dan resiko K3 tersebut. Hasil dari form ini kemudian dapat dijadikan dasar perencanaan penerapan dan pelaksanaan K3 (Keselamatan dan Kesehatan Kerja) di tempat kerja Identifikasi Bahaya 




Gambar 2. Form Identifikasi Bahaya dan Penilaian Resiko Sumber : Wahyudi B. Agung (BAB 2 - Identifikasi Bahaya)

\section{Metodologi Penelitian}

\section{Metode Pengumpulan Data}

Pada tahap ini akan dirancang lembar checklist yang berisi item - item pertanyaan yang disusun berdasarkan butir - butir yang harus di perhatikan dalam konsep 5R dan penyesuain terhadap kondisi laboratorium.

\section{Identifikasi Potensi Bahaya}

Data yang diperlukan yaitu:

1. Primer, yaitu data kondisi daerah kerja yang dianggap rawan kecelakaan kerja, dan

data pengamatan alat pelindung diri yang dipakai pekerja

2. Data sekunder, yaitu data kecelakaan kerja selama periode 2015 hingga 2018.

\section{Metode Pengolahan Data}

\section{a. Metode Checklist}

Pengolahan data dilakukan dengan menggunakan metode Checklist dengan langkah-langkah sebagai berikut:

1. Identifikasi metode pemecahan masalah, metode yang digunakan pada penelitian ini adalah pendekatan dengan $5 \mathrm{R}$.

2. Identifikasi area pengamatan
Pada tahap ini dilakukan survei dan mengamati area kerja sebelum penerapan $5 \mathrm{R}$ untuk membuat checklist dengan kondisi pada area bahan di gudang laboratorium.

3. Perancangan checklist audit sheet Pada tahap ini dirancang lembar checklist yang berisi item-item pertanyaan, disusun berdasarkan butir-butir yang harus dilakukan dalam konsep 5R dan penyesuain terhadap kondisi laboratorium.

\section{b. Metode diagram Fishbone dan Diagram Pareto}

Tinjauan awal kondisi dilakukan dengan cara mengidentifikasi potensi bahaya dan penilaian risiko. Identifikasi potensi bahaya dilakukan dengan mengisi kolom bahaya, akibat dan risk matrix pada form observasi. Kolom risk matrix terdiri dari kolom probability, severity, risk dan signifikasi risk di isi dengan menggunakan proses penilaian risiko menurut Tarwaka (2014).

Setelah tingkat potensi bahaya tertinggi diperoleh maka dilakukan analisis risiko dengan cara peninjauan sebab akibat kejadian yang membahayakan dengan menggunakan diagram fishbone guna mengetahui faktor apa saja yang menyebabkan timbulnya potensi bahaya. 


\section{Diagram Alir Penelitian}

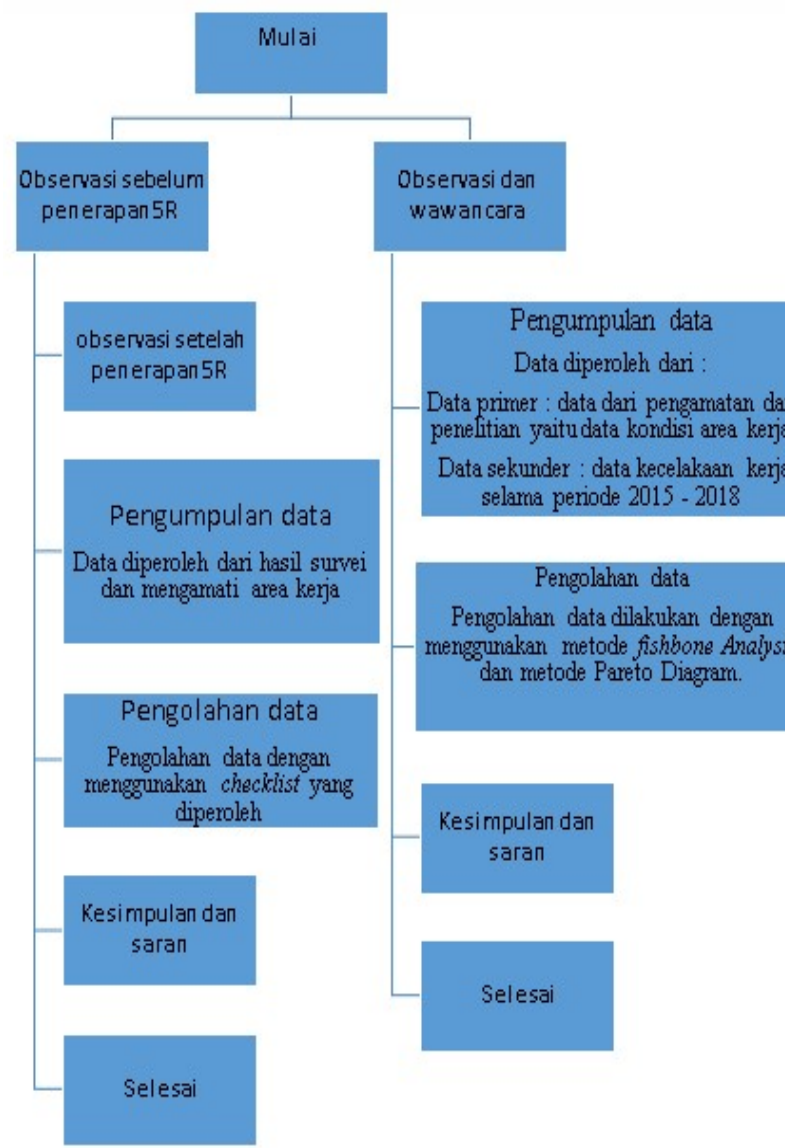

Kegiatan observasi keadaan area kerja gudang dilakukan dengan menggunakan checklist 5R. Hasil pengukuran keadaan area sebelum diterapkannya metode $5 \mathrm{R}$ dapat dilihat pada tabel berikut

\section{Hasil dan Pembahasan}

Analisis Data

1. Hasil Observasi Keadaan Area Gudang

Sebelum Diterapkan Metode 5R

Tabel 2. Hasil Evaluasi Sebelum Penerapan Metode 5R 


\begin{tabular}{|c|c|c|c|c|c|c|}
\hline \multicolumn{2}{|r|}{$\begin{array}{l}\text { Pemberian Skor untuk setiap pernyataan berdasarkan aplikasi: } 0-20 \%= \\
\text { skor } 1,21 \% \text { - } \\
40 \%=\text { skor } 2,41 \%-60 \%=\operatorname{skor} 3,61 \%-80 \%=\text { skor } 4,81 \%-100 \% \\
=\text { skor5 }\end{array}$} & \multicolumn{5}{|c|}{ SKOR } \\
\hline No & Pernyataan & $\mathbf{l}$ & 2 & 3 & 4 & 5 \\
\hline 1 & $\begin{array}{l}\text { Sermua orang telah memberikan kontribusi terhadap proses } \\
\text { tagging untuk menyingkirkan iterm item yang tidak diperlukan. }\end{array}$ & $\sqrt{ }$ & & & & \\
\hline 2 & $\begin{array}{l}\text { Sernua orang telah mengikuti prosedur untuk melakukan proses } \\
\text { SR. }\end{array}$ & $\sqrt{ }$ & & & & \\
\hline 3 & $\begin{array}{l}\text { Sernua bahan dan peralatan ditempatkan atau disimpan pada tempat } \\
\text { yang telah ditentukan. } \\
\text { Telah ada penunjukan personil secara formal dar manajemen } \\
\text { untuk bertanggung jawab memelikara bahan serbuk, bahan cair } \\
\text { serta bahan obat - obattan. }\end{array}$ & $\sqrt{ }$ & & & & \\
\hline 4 & $\begin{array}{l}\text { Sernua area gudang bahan tarmpak bersih dan terpelihara dengan } \\
\text { sangat baik dan teratur. }\end{array}$ & $\sqrt{ }$ & & & & \\
\hline 5 & $\begin{array}{l}\text { Terdapat } 5 \mathrm{R} \text { V isual Board, poster-poster, dan bentuk-bentuk visual } \\
\text { lainnya yang memungkinkan semua orang mengetahui dan } \\
\text { mengerti tentang } 5 \mathrm{R} \text { dalam organisasi. }\end{array}$ & $\sqrt{ }$ & & & & \\
\hline 6 & $\begin{array}{l}\text { Terdapat prosedur dan instruksi kerja tentang 5R yang } \\
\text { diperbahanui secara berkala. }\end{array}$ & $\sqrt{ }$ & & & & \\
\hline 7 & $\begin{array}{l}\text { Semua karyawan dan manajemen telah memperoleh pelatihan } \\
\text { secara formal tentang } 5 \mathrm{R} \text { agar memahami tentang prinsip-prinsip } \\
\mathrm{SR} \text {. }\end{array}$ & $\sqrt{ }$ & & & & \\
\hline 8 & $\begin{array}{l}\text { Terdapat sistem penghargaan dan pengakuan yang berlaku secara } \\
\text { formal sebagai alat motivasi dalam penerapan } 5 \mathrm{R} \text {. }\end{array}$ & $\sqrt{ }$ & & & & \\
\hline 9 & $\begin{array}{l}\text { Terdapat sistem audit } 5 \mathrm{R} \text { yang dilakukan secara berkala. Skor } \\
\text { audit dikomunikasikan secara visual melalui } 5 \mathrm{R} \text { visual board. } \\
\text { Terdapat personil atau bagian audit } 5 \mathrm{R} \text { yang bertanggung jawab } \\
\text { secara formal dalam organisasi. }\end{array}$ & $\sqrt{ }$ & & & & \\
\hline & SKOR TOTAL & \multicolumn{5}{|c|}{$1 \times 9$} \\
\hline & Maksimum Skor total $=45$ & \multicolumn{5}{|c|}{$(9 / 45) \times 100$} \\
\hline & SKOR Program $5 S$ (persen) $=(11 / 45) \times 100=24,44$ & \multicolumn{5}{|c|}{ SKOR 5R } \\
\hline \multicolumn{2}{|r|}{$\begin{array}{l}\text { Kriteria Evaluasi Program SR ( Skor SR ) : } \\
0-20 \%=\text { Sangat Buruk, } 21 \% \text { - } 40 \%=\text { Buruk, } 41 \% \text { - } 60 \%=\text { Cuku, } \\
61 \%-80 \%=\text { Baik, } 81 \% \text { - } 100 \% \text { = Sangat Baik }\end{array}$} & \multicolumn{5}{|c|}{$20 \%$} \\
\hline
\end{tabular}

Keterangan :

Skala 1 : tidak pernah

Skala 2 : jarang

Skala 3 : kadang - kadang

Skala 4 : sering

Skala 5 : selalu

\section{Pengolahan Data}

\section{a. Lembar Hasil Temuan}

Jika dilihat dari analisis data di tabel 2 terlihat terdapat banyak masalah yang ditemukan sebelum penerapan metode $5 \mathrm{R}$ di area gudang karena nilai total masih jauh dari 152 . Kondisi pada area gudang yang tidak terorganisir membuat area kerja menjadi tidak beraturan. Masalah yang ditemukan pada area gudang dapat dilihat pada Tabel 3 berikut ini : 


\begin{tabular}{|c|c|c|}
\hline \multicolumn{3}{|c|}{ RINGKAS } \\
\hline No & $\begin{array}{l}\text { Membedakan antara apa yang dibutuhkan } \\
\text { dan tidak dibutuhkan }\end{array}$ & Catatan Temuan \\
\hline 1 & $\begin{array}{l}\text { Terdapat prosedur tertulis untuk eliminasi atau } \\
\text { pembuangan item - item tidak terpakai }\end{array}$ & Tidak terdapat prosedur untuk proses eliminasi. \\
\hline 2 & Terdapat alat tidak di butuhkan & $\begin{array}{l}\text { Barang yang tidak dibutuhkan adalah tutup botol } \\
\text { bahan yang rusak, } \\
\text { botol - botol bahan kimia kosong, wadah bahan } \\
\text { sudah tidak layak pakai, } \\
\text { plastik - plastik kemasan wadah bahan kimia, pot - } \\
\text { pot obat bekas, bahan - bahan kimia yang sudah } \\
\text { rusak. }\end{array}$ \\
\hline \multicolumn{3}{|c|}{ RAPI } \\
\hline No & $\begin{array}{l}\text { Sebuah tempat untuk segala sesuatu dan } \\
\text { segala sesuatu di tempatnya }\end{array}$ & Catatan Temuan \\
\hline 3 & Semua item memiliki lokasi tertentu & $\begin{array}{l}\text { Barang yang tersembunyi yang tidak terpakai : } \\
\text { terdapat gelas - gelas kimia yang seharusnya ada di } \\
\text { gudang alat, pipet volum dan pipet gondok yang } \\
\text { berhamburan } \\
\text { serta batang pengaduk dan spatula yang berserakan } \\
\text { di gudang bahan. }\end{array}$ \\
\hline 4 & Semua item mendapatkan lokasi yang tepat & $\begin{array}{l}\text { Item yang tidak pada tempatnya dan banyak nya } \\
\text { bahan berhamburan di lantai area gudang bahan }\end{array}$ \\
\hline 5 & $\begin{array}{l}\text { Terdapat label/tanda yang mengindikasi area } \\
\text { lemari penyimpanan }\end{array}$ & $\begin{array}{l}\text { Tanda penyimpanan yang terdapat dilemari bahan } \\
\text { telah pudar dan rusak. }\end{array}$ \\
\hline
\end{tabular}

\begin{tabular}{|c|c|c|}
\hline 7 & $\begin{array}{l}\text { Terdapat indikator yang jelas tentang status } \\
\text { persediaan bahan }\end{array}$ & $\begin{array}{l}\text { Belum adanya buku besar tentang stok persediaan } \\
\text { bahan. }\end{array}$ \\
\hline 8 & $\begin{array}{l}\text { Tempat penyimpanan bahan teridentifikasi } \\
\text { secara jelas dimana bahan serbuk, botol } \\
\text { putih cair, maupun botol hitam cair. }\end{array}$ & $\begin{array}{l}\text { Bahan - bahan yang ada di area gudang belum } \\
\text { teridentifikasi dengan jelas. }\end{array}$ \\
\hline \multicolumn{3}{|c|}{ RESIK } \\
\hline No & $\begin{array}{l}\text { Disiplin rutin menjaga tempat kerja yang } \\
\text { bersih dan terorganisir }\end{array}$ & Catatan Temuan \\
\hline 9 & $\begin{array}{l}\text { Area gudang dan lemari penyimpanan terlihat } \\
\text { bersih }\end{array}$ & Terdapat banyak debu dan kotoran dimana- mana \\
\hline 10 & $\begin{array}{l}\text { Sampah dan daur ulang di kumpulkan dan } \\
\text { dibuang dengan benar }\end{array}$ & $\begin{array}{l}\text { Sampah tidak dibuang dan sampah daur ulang } \\
\text { bergeletakkan }\end{array}$ \\
\hline 11 & $\begin{array}{l}\text { Daerah area gudang dibersihkan dan dipelihara } \\
\text { secara teratur }\end{array}$ & $\begin{array}{l}\text { Kebersihan area gudang tidak dipelihara dengan } \\
\text { baik }\end{array}$ \\
\hline 12 & Semua lantai selalu bersih dan mengkilap & $\begin{array}{l}\text { Lantai tidak terlihat bersih karena terdapat banyak } \\
\text { kotoran dan tumpahan - tumpahan bahan kimia } \\
\text { serbuk maupun } \\
\text { cairan }\end{array}$ \\
\hline 13 & $\begin{array}{l}\text { Pembersihan selalu dilakukan berdasarkan } \\
\text { aktivitas checklist }\end{array}$ & $\begin{array}{l}\text { Tidak terdapat checklist pembersihan di area } \\
\text { gudang }\end{array}$ \\
\hline 14 & $\begin{array}{l}\text { Terdapat rotasi tanggung jawab pembersihan } \\
\text { dalam } \\
\text { area kerja yang ditentukan }\end{array}$ & Tidak ada rotasi tanggung jawab \\
\hline 15 & $\begin{array}{l}\text { Tempat kerja yang bersih dan teratur telah } \\
\text { menjadi } \\
\text { kebiasaan dari semua karyawan }\end{array}$ & Tidak ada kebiasaan untuk menjaga kebersihan \\
\hline
\end{tabular}




\begin{tabular}{|c|c|c|}
\hline \multicolumn{3}{|c|}{ RESIK } \\
\hline No & $\begin{array}{l}\text { Disiplin rutin menjaga tempat kerja yang } \\
\text { bersih dan terorganisir }\end{array}$ & Catatan Temuan \\
\hline 9 & $\begin{array}{l}\text { Area gudang dan lemari penyimpanan terlihat } \\
\text { bersih }\end{array}$ & Terdapat banyak debu dan kotoran dimana- mana \\
\hline 10 & $\begin{array}{l}\text { Sampah dan daur ulang di kumpulkan dan } \\
\text { dibuang dengan benar }\end{array}$ & $\begin{array}{l}\text { Sampah tidak dibuang dan sampah daur ulang } \\
\text { bergeletakkan }\end{array}$ \\
\hline 11 & $\begin{array}{l}\text { Daerah area gudang dibersihkan dan dipelihara } \\
\text { secara teratur }\end{array}$ & $\begin{array}{l}\text { Kebersihan area gudang tidak dipelihara dengan } \\
\text { baik }\end{array}$ \\
\hline 12 & Semua lantai selalu bersih dan mengkilap & $\begin{array}{l}\text { Lantai tidak terlihat bersih karena terdapat banyak } \\
\text { kotoran dan tumpahan - tumpahan bahan kimia } \\
\text { serbuk maupun } \\
\text { cairan }\end{array}$ \\
\hline 13 & $\begin{array}{l}\text { Pembersihan selalu dilakukan berdasarkan } \\
\text { aktivitas checklist }\end{array}$ & $\begin{array}{l}\text { Tidak terdapat checklist pembersihan di area } \\
\text { gudang }\end{array}$ \\
\hline 14 & $\begin{array}{l}\text { Terdapat rotasi tanggung jawab pembersihan } \\
\text { dalam } \\
\text { area kerja yang ditentukan }\end{array}$ & Tidak ada rotasi tanggung jawab \\
\hline 15 & $\begin{array}{l}\text { Tempat kerja yang bersih dan teratur telah } \\
\text { menjadi } \\
\text { kebiasaan dari semua karyawan }\end{array}$ & Tidak ada kebiasaan untuk menjaga kebersihan \\
\hline \multicolumn{3}{|c|}{ RAWAT } \\
\hline No & $\begin{array}{l}\text { Mencegah daerah dari memiliki kondisi } \\
\text { operasi normal }\end{array}$ & Catatan Temuan \\
\hline 16 & $\begin{array}{l}\text { Staf terlatih dan sepenuhnya memahami } \\
\text { prosedur } 5 \mathrm{R}\end{array}$ & Belum dilakukannya training mengenai konsep $5 \mathrm{~S}$ \\
\hline 17 & Standar $5 R$ jelas ditampilkan & Tidak terdapat standar $5 \mathrm{R}$ \\
\hline 18 & Udara bersih dan tidak berbau & $\begin{array}{l}\text { Udara berbau dan pengap karna blower yang } \\
\text { terdapat di area gudang tidak berfungsi dengan baik }\end{array}$ \\
\hline 19 & $\begin{array}{l}\text { Terdapat sistem dan prosedur tertulis tentang } \\
\text { 5R di area-area kerja }\end{array}$ & Tidak terdapat prosedur di area kerja gudang \\
\hline
\end{tabular}

\begin{tabular}{|c|l|l|}
\hline \multicolumn{2}{|c|}{ RAJIN } \\
\hline No & Berpegang pada aturan (disiqlin diri) & Catatan Temuan \\
\hline 20 & $\begin{array}{l}\text { Setiap orang yang terlibat dalam kegiatan } \\
\text { peningkatan }\end{array}$ & Belum ada sosialisasi mengenai konsep 5R \\
\hline 21 & $\begin{array}{l}\text { Permbersihan dan pekerjaan prosedur standar } \\
\text { diikuti }\end{array}$ & Belum ada standar 5R \\
\hline 22 & Dokumentasi 5R dan instruksi yang saat ini & Belum ada dokumentasi dan instruksi kerja \\
\hline & $\begin{array}{l}\text { Setiap orang hadir dan terlibat aktif dalam } \\
\text { meeting } \\
23\end{array}$ & Belum ada meeting mengenai konsep 5R \\
\hline & $\begin{array}{l}\text { Terdapat peraturan dan prosedur tertulis } \\
\text { tentang 5R }\end{array}$ & \\
24 & yang dipahami oleh semua karyawan & Tidak terdapat prosedur tertulis \\
\hline 25 & $\begin{array}{l}\text { Peraturan dan prosedur tertulis tentang 5R } \\
\text { dihargai/diakui dan diikuti oleh semua } \\
\text { karyawan }\end{array}$ & Belum ada peraturan \\
\hline
\end{tabular}

\section{Tuntutan Kebutuhan}

Hasil evaluasi 5R yang dicapai masih sangat rendah dan berada dalam kategori sangat buruk, oleh karena itu perlu dilakukan perbaikan dengan terlebih dahulu mengidentifikasi tuntutan kebutuhan. Identifikasi tuntutan kebutuhan perancangan berdasarkan masalah yang terjadi pada hasil temuan. Kondisi tersebut yang mendasari kebutuhan perancangan yang akan dilakukan. Kebutuhan yang diperlukan pada area gudang bahan kimia adalah:

1. Prosedur eliminasi. 
2. Tagging pada bahan yang rusak.

3. Lokasi untuk item pada seluruh area gudang.

4. Label bahan kimia yang akan diletakkan di area penyimpanan.

5. Label lokasi area penyimpanan.

6. Lokasi barang di tempat yang mudah dijangkau.

7. Tempat sampah di dalam area gudang.

8. Checklist pembersihan.

\section{Hasil Evaluasi Penerapan Metode 5R}

Setelah melakukan perbaikan area kerja dengan penerapan metode $5 \mathrm{R}$ maka
9. Jadwal piket.

10. Sosialisasi peranan 5R kepada karyawan.

11. Instruksi Kerja dan poster standar $5 \mathrm{R}$.

12. Visual board di dalam area gudang bahan.

13. Renovasi lantai gudang bahan.

14. Reward untuk karyawan.

selanjutnya adalah mengevaluasi hasil penerapan metode $5 \mathrm{R}$. Hasil penilaian penerapan $5 \mathrm{R}$ pada area gudang bahan kimia dapat dilihat pada Tabel 4 .

Tabel 4. Hasil Evaluasi Setelah Penerapan Metode 5R

\begin{tabular}{|c|c|c|c|c|c|c|}
\hline \multicolumn{2}{|r|}{  } & \multicolumn{5}{|c|}{ SKOR } \\
\hline No & Permyrataan & $\mathbf{1}$ & 2 & 3 & 4 & 5 \\
\hline 1 & $\begin{array}{l}\text { Serrou orang telah memberkankorthbusi terhadap proses } \\
\text { togging untuk menyinglirkan item-item yamg tidak } \\
\text { diperbukan. }\end{array}$ & & & & & $\sqrt{ }$ \\
\hline 2 & $\begin{array}{l}\text { Servia orang telah menglout pros edururbik melaholan } \\
\text { proses } 5 \mathrm{R} \text {. }\end{array}$ & & & & & $\sqrt{ }$ \\
\hline 3 & $\begin{array}{l}\text { Serrua bahandan peralatan ditempatkan atau dis inqampaia } \\
\text { tempat yang telah ditentıkan. } \\
\text { Telah ada perunjukan pers onil secara formaldamimajemen } \\
\text { untuk bertanggung jawab memelihara bahan serbuk, b ahm } \\
\text { cair serta bahan ob at - ob attan. }\end{array}$ & & & & & $\sqrt{\prime}$ \\
\hline 4 & $\begin{array}{l}\text { Sernua area gudang b ahan tampakbes ihdanterpelihara } \\
\text { dengan } \\
\text { sangatb aik dan teratur. }\end{array}$ & & & & $\sqrt{ }$ & \\
\hline 5 & 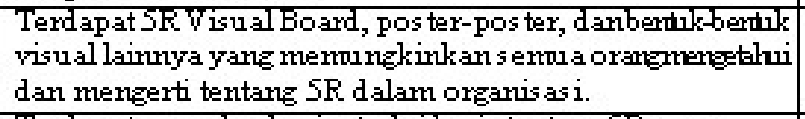 & & & & & $\sqrt{ }$ \\
\hline 6 & $\begin{array}{l}\text { Terdapat prosedur danins tolsi kerja tentang SR yang } \\
\text { diperb ahani secaraberkala. }\end{array}$ & & & & $\sqrt{ }$ & \\
\hline 7 & $\begin{array}{l}\text { Sernia karyawan dan manajemen telah memperoleh } \\
\text { pelatihan secara formal tentanz SR agar memahami tentang } \\
\text { prinsip-prinsip SR. }\end{array}$ & & $\sqrt{ }$ & & & \\
\hline 8 & 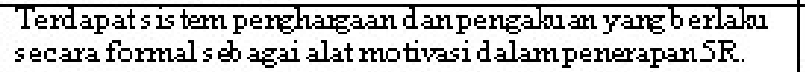 & & $\sqrt{\prime}$ & & & \\
\hline 9 & 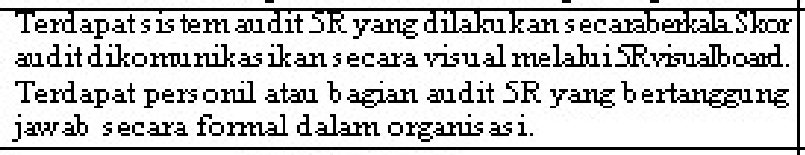 & & $\sqrt{ }$ & & & \\
\hline & SKOR TOTAL & \multicolumn{5}{|c|}{$(1 \times 0)+(2 \times 3)+(3 \times 0)+(4 \times 2)+(5 \times 4)$} \\
\hline & Maks irnum Skor total $=45$ & \multicolumn{5}{|c|}{$(34 / 45) \times 100$} \\
\hline \multirow{2}{*}{\multicolumn{2}{|c|}{$\begin{array}{l}\text { Kriteria Evahias i Frogram SR ( Skor SR): } \\
0-20 \%=\text { Sangat Buruk, } 21 \%-40 \%=\text { Buruk, } 41 \%-60 \%= \\
\text { Cukp, } 61 \%-80 \%=\text { Baik, } 81 \%-100 \%=\text { Sangat Baik }\end{array}$}} & \multicolumn{5}{|c|}{ SKOR 5R } \\
\hline & & \multicolumn{5}{|c|}{$75,6 \%$} \\
\hline
\end{tabular}

Sumber : Hasil Pengamatan

Keterangan:

Skala 1 : tidak pernah

Skala 3 : kadang - kadang
Skala 2 : jarang

Skala 4 : sering
Skala 5 : selalu 
Identifikasi Potensi Bahaya dengan Metode Pareto

yang akan di prioritaskan untuk segera di selesaikan dengan bentuk diagram pareto.
Berikut merupakan persentase insiden kecelakaan kerja dari urutan ranking tertinggi hingga terendah

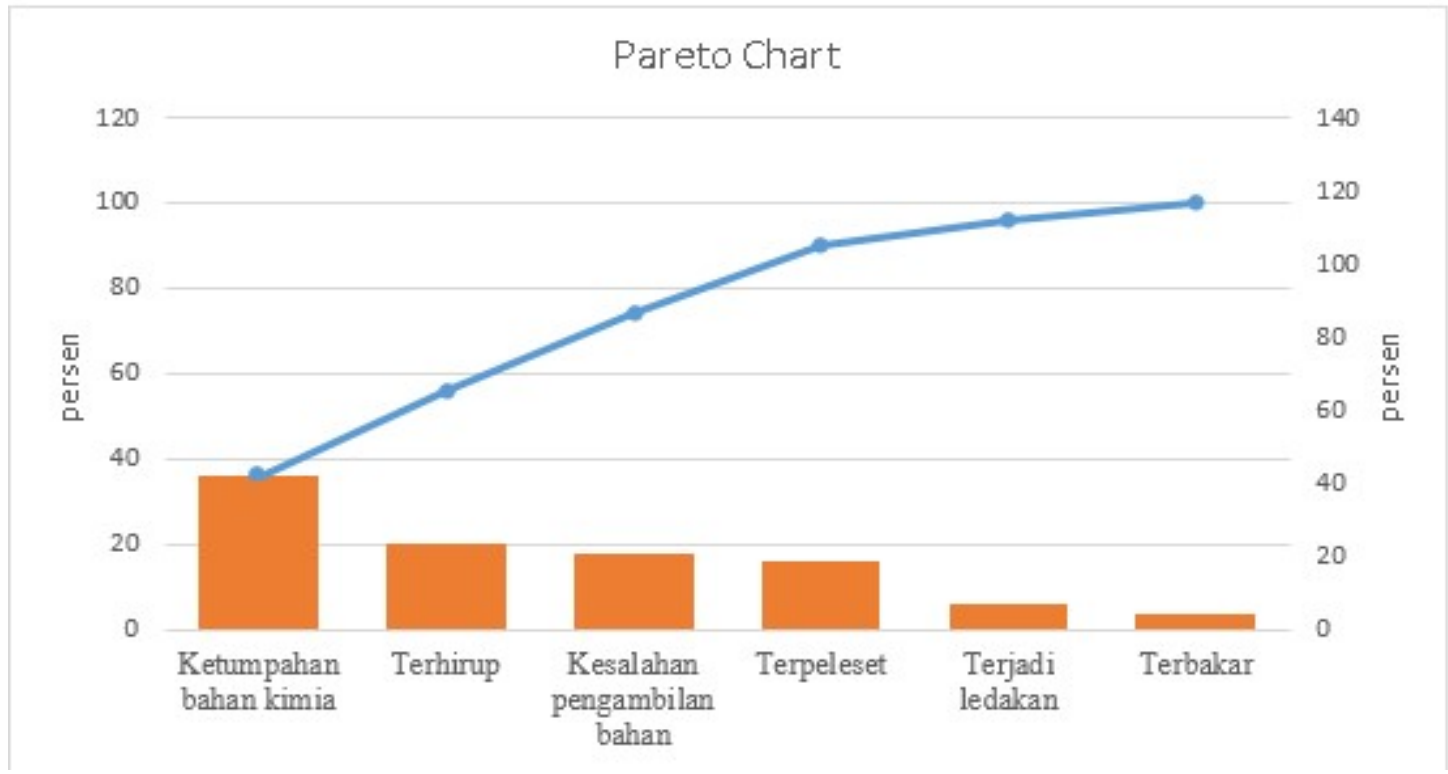

Gambar 3. Diagram Pareto berdasarkan jenis kecelakaan kerja Sumber : DataPenelitian

Identifikasi Akar Masalah Potensi Bahaya dengan Metode Fishbone

Berikut adalah diagram tulang ikan dari insiden kecelakaan kerja yang di ranking dari tiga tertinggi untuk di identifikasi akar penyebab potensi bahaya:

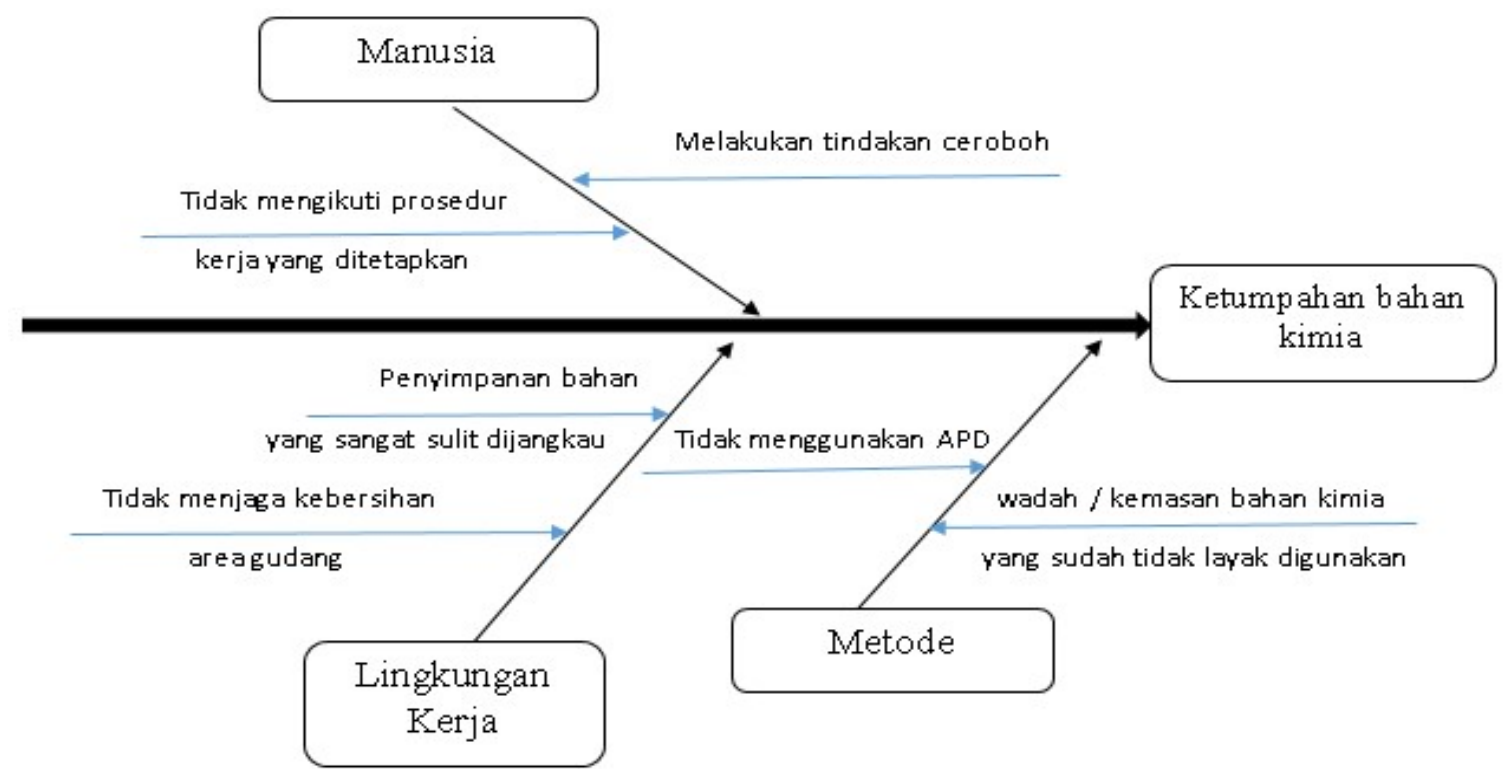

Gambar 4. Diagram Tulang Ikan Ketumpahan Bahan Kimia Sumber: Hasil Penelitian 


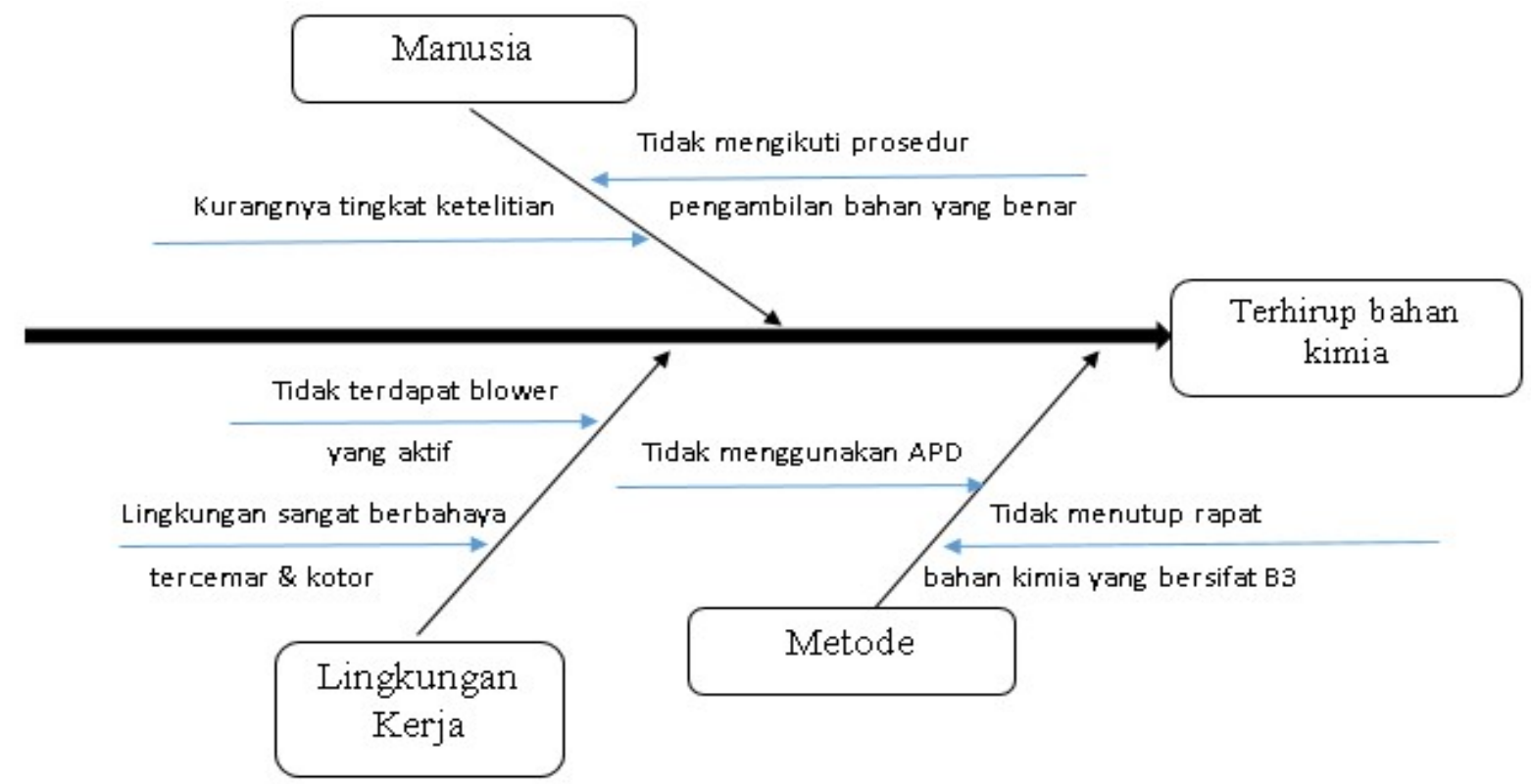

Gambar 5. Diagram Tulang Ikan Terhirup Bahan Kimia Sumber : Hasil Penelitian

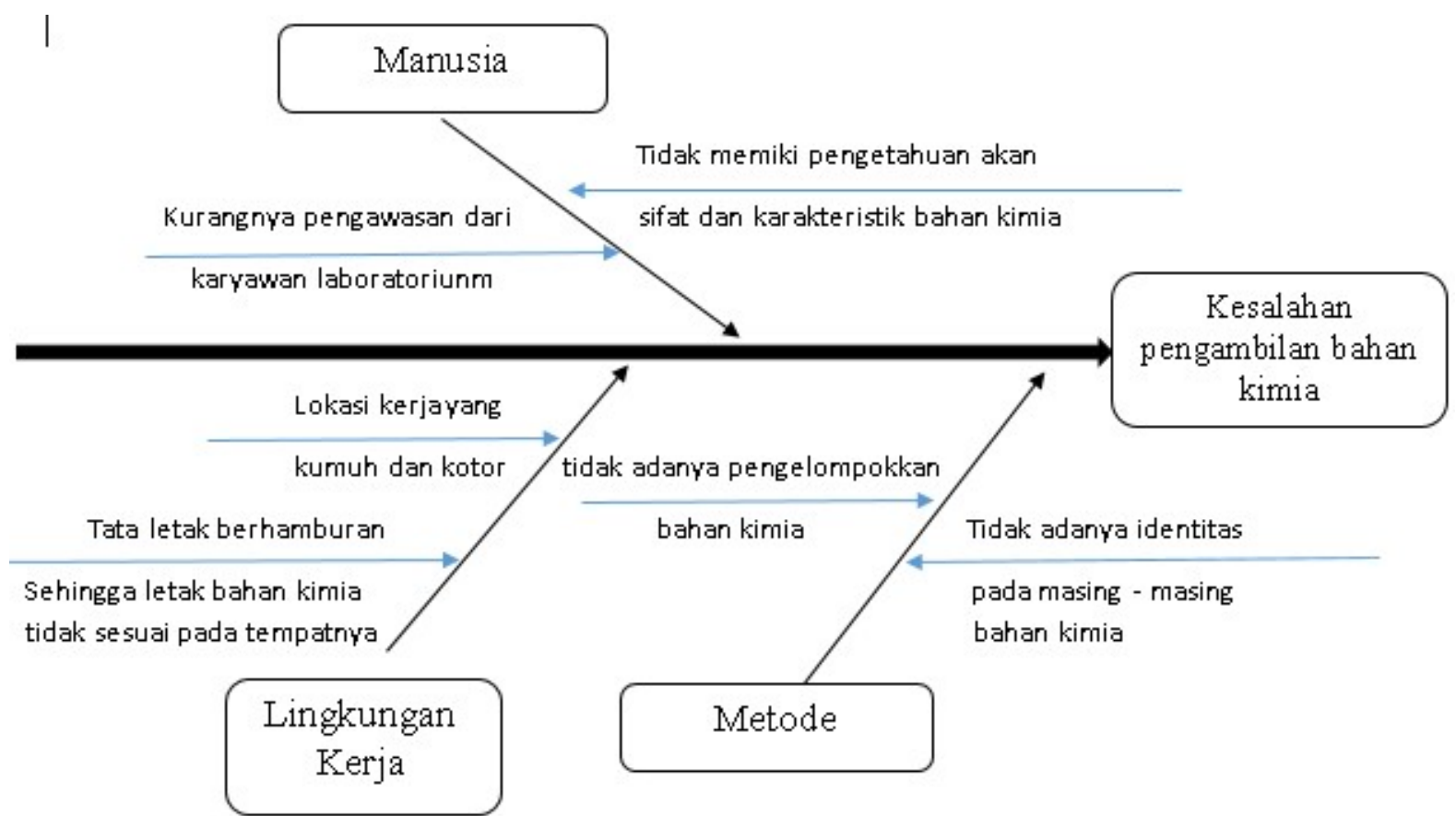

Gambar 6. Diagram Tulang Ikan Kesalahan Pengambilan Bahan Kimia Sumber : Hasil Penelitian

\section{Data Kecelakaan Kerja Setelah Penerapan 5R}

Tabel 5. Data Kecelakaan setelah penerapan 5R dari bulan April - September 2019 


\begin{tabular}{|c|c|c}
\hline No & Tahun & Jenis Kecelakaan \\
\hline 1. & April & $0 \mathrm{Kali}$ \\
\hline 2. & Mei & $0 \mathrm{Kali}$ \\
\hline 3. & Juni & $0 \mathrm{Kali}$ \\
\hline 4. & Juli & $0 \mathrm{Kali}$ \\
\hline 5. & Agustus & $0 \mathrm{Kali}$ \\
\hline 6. & September & $0 \mathrm{Kali}$ \\
\hline & Total & $\mathbf{0 ~ K a l i}$ \\
\hline
\end{tabular}

Persentase Perbandingan Kecelakaan Kerja

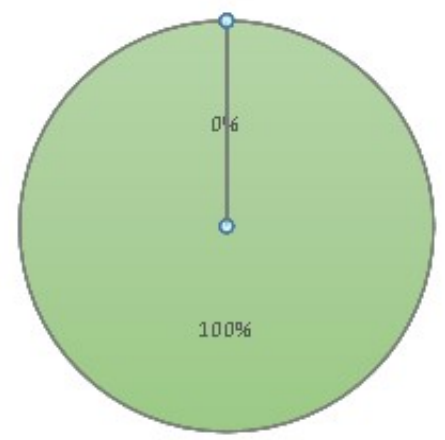

Gebelum Penerapan 5R घSetelah Penerapan 5R

Sumber: Data Laboratorium MIPA

\section{Hasil Penerapan 5R di Gudang Bahan Kimia}

1. Ringkas/Pemilahan

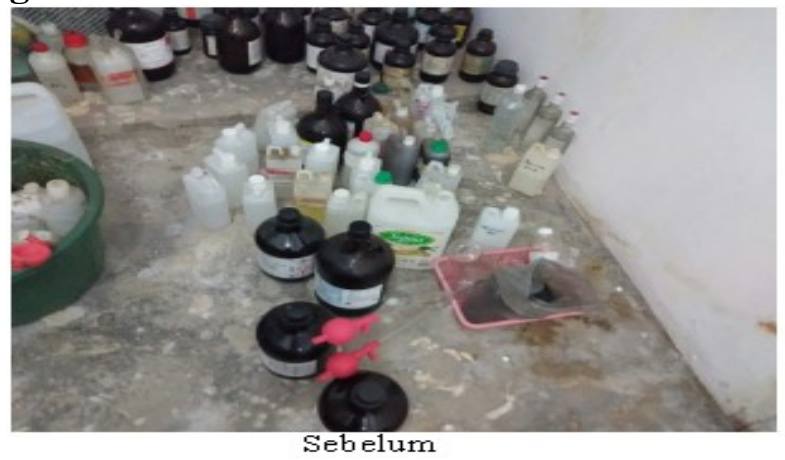

Gambar 7. Perbandingan Area Gudang Penerapan Metode Ringka

\section{Penataan/Rapi (Seiton)}

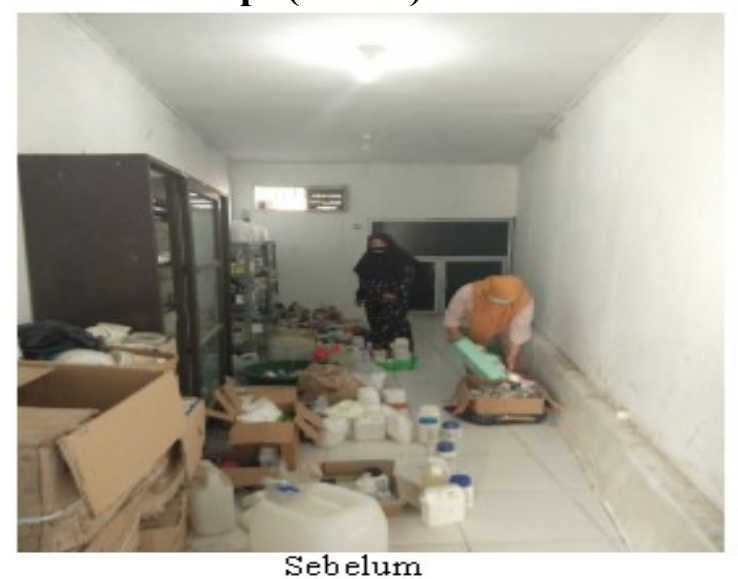

Gambar 8. Perbandingan Area Gudang Menggunakan Metode Rapi

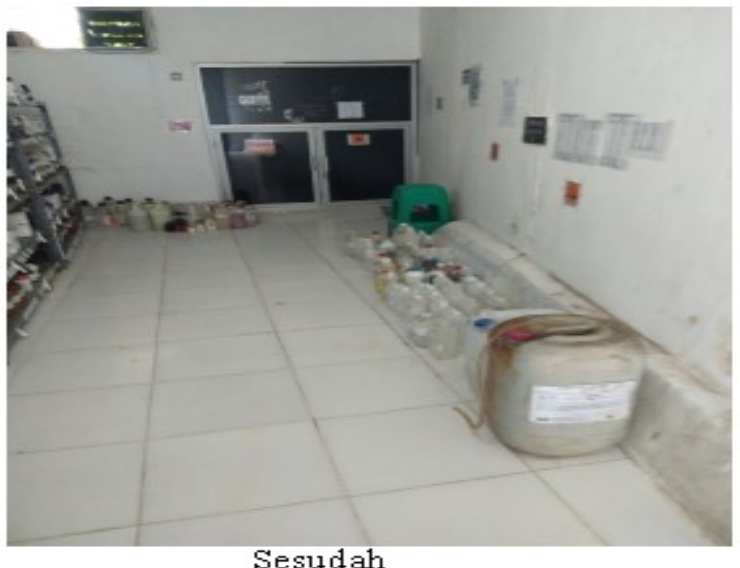

k/membersihkan (Seiso)

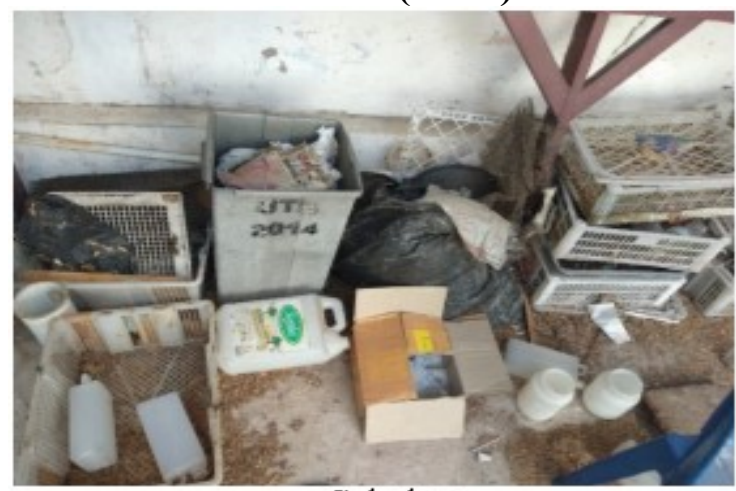

Sebelum

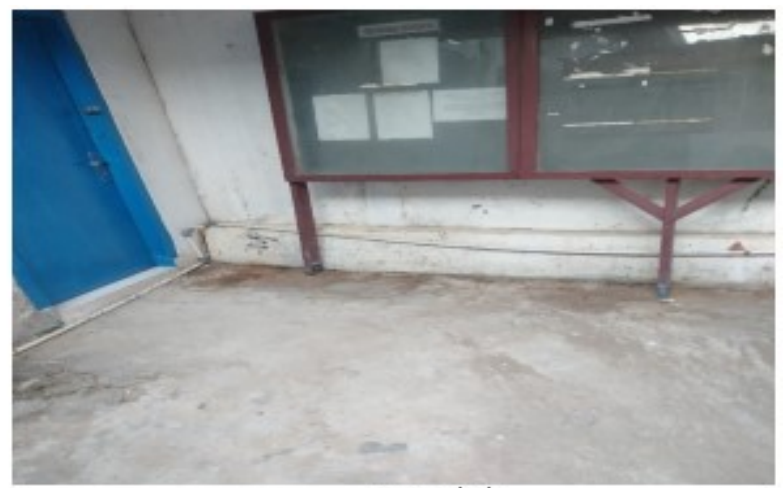

Sesudah 
Gambar 9. Perbandingan Area Gudang Menggunakan Metode Resik

\section{Rawat/Pemantapan (Seiketsu)}

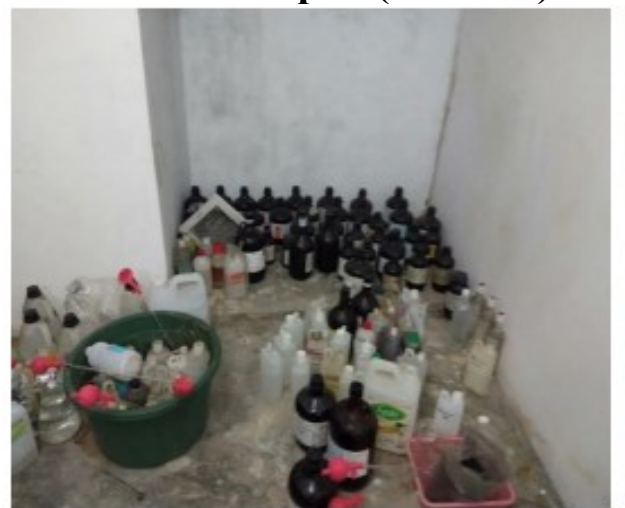

Sebelum

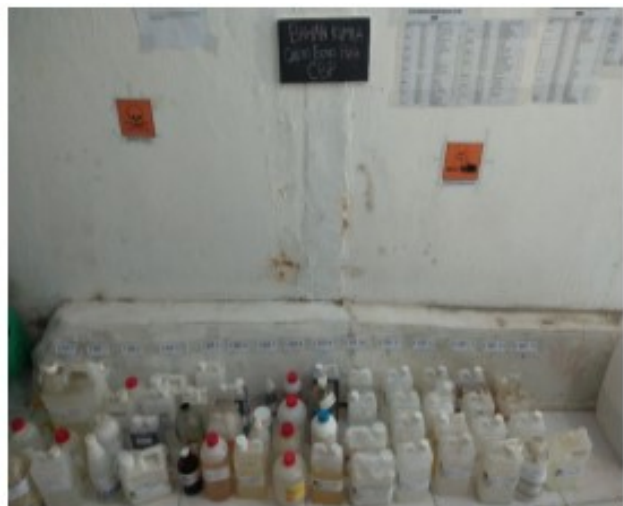

Sesudah

Gambar 10. Perbandingan Area Gudang Menggunakan Metode Rawat

\section{Rajin/Pembiasaan (Shitsuke)}

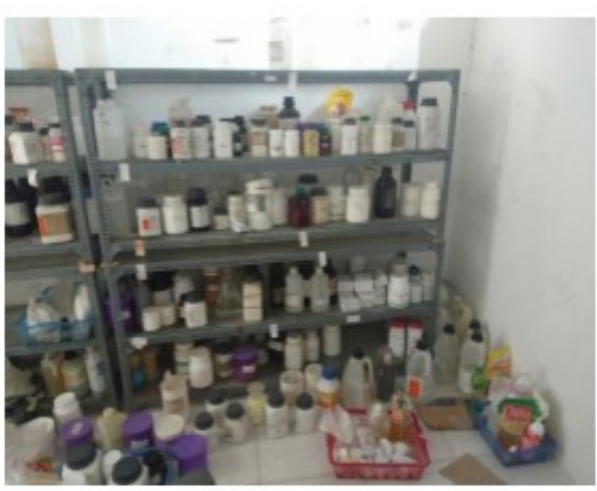

Sebelum



Sesudah

Gambar 11.Perbandingan Area Gudang Menggunakan Metode Rajin

\section{Tindakan Perbaikan}

Tabel 6.Tindakan Perbaikan Terhirup Bahan Kimia

\begin{tabular}{|c|c|c|c|c|c|c|}
\hline Faktor & What & Who & Where & When & Why & How \\
\hline \multirow[t]{2}{*}{ Manusia } & $\begin{array}{l}\text { Tidak mengikuti } \\
\text { prosedur } \\
\text { pengambilan } \\
\text { bahan yang } \\
\text { benar }\end{array}$ & \multirow[t]{2}{*}{$\begin{array}{l}\text { PraktikanMahawasiswa } \\
\text { \& seluruh karyawan } \\
\text { laboratorium }\end{array}$} & \multirow[t]{2}{*}{$\begin{array}{l}\text { Gudang } \\
\text { bahan kimia }\end{array}$} & \multirow[t]{2}{*}{$\begin{array}{l}\text { Pada saat } \\
\text { pengambilan } \\
\text { bahan kimia }\end{array}$} & \multirow[t]{2}{*}{$\begin{array}{l}\text { Untuk menghindari } \\
\text { kecelakaan pada } \\
\text { terhirupmya bahan } \\
\text { kimia }\end{array}$} & \multirow[t]{2}{*}{$\begin{array}{l}\text { Dengan cara mengawasi dan } \\
\text { mermberikan pengarahan } \\
\text { terhadap prosedur pengambilan } \\
\text { bahan yang benar }\end{array}$} \\
\hline & $\begin{array}{l}\text { Kurangnya } \\
\text { tingkat ketelitian }\end{array}$ & & & & & \\
\hline \multirow[t]{2}{*}{ Metode } & $\begin{array}{l}\text { Tidak } \\
\text { menggunakan } \\
\text { APD }\end{array}$ & \multirow[t]{2}{*}{$\begin{array}{l}\text { PraktikanMahawasiswa } \\
\text { \& seluruh karyawan } \\
\text { laboratorium }\end{array}$} & \multirow[t]{2}{*}{$\begin{array}{l}\text { Gudang } \\
\text { bahan kimia }\end{array}$} & \multirow[t]{2}{*}{$\begin{array}{l}\text { Pada saat } \\
\text { pengarnbilan } \\
\text { bahan kimia }\end{array}$} & $\begin{array}{l}\text { Agar penggunaan } \\
\text { APD lebih } \\
\text { termonitor }\end{array}$ & $\begin{array}{l}\text { Dengan cara mengecek } \\
\text { kelengkapan APD yang } \\
\text { digurakan pada saat masuk } \\
\text { kedalam gudang }\end{array}$ \\
\hline & $\begin{array}{l}\text { Tidak menutup } \\
\text { rapat bahan } \\
\text { kimia yang } \\
\text { bersifat B3 }\end{array}$ & & & & $\begin{array}{l}\text { Agar tidak terhinup } \\
\text { bahan kimia yang } \\
\text { berbahaya }\end{array}$ & $\begin{array}{l}\text { Dengan cara mengawasi proses } \\
\text { pengambilan bahan kimia agar } \\
\text { tidak teriadi kesalahan }\end{array}$ \\
\hline \multirow[t]{2}{*}{ Lingkungan } & $\begin{array}{l}\text { Lingkungan } \\
\text { sangat berbahaya } \\
\text { dan kotor }\end{array}$ & \multirow[t]{2}{*}{$\begin{array}{l}\text { PraktikarMahawasiswa } \\
\text { \& seluruh karyawan } \\
\text { laboratorium }\end{array}$} & \multirow[t]{2}{*}{$\begin{array}{l}\text { Gudang } \\
\text { bahan kimia }\end{array}$} & \multirow[t]{2}{*}{$\begin{array}{l}\text { Pada saat } \\
\text { pengambilan } \\
\text { bahan kimia }\end{array}$} & $\begin{array}{l}\text { Agar area gudang } \\
\text { tidak tercemar bahan } \\
\text { berbahays }\end{array}$ & $\begin{array}{l}\text { Dengan cara membuat ventilas } \\
\text { udara didalam area gudang }\end{array}$ \\
\hline & $\begin{array}{l}\text { Tidak terdapat } \\
\text { blower yang } \\
\text { aktif }\end{array}$ & & & & $\begin{array}{l}\text { Agar sirkulasi } \\
\text { didalarm area gudang } \\
\text { meriadi lancar }\end{array}$ & $\begin{array}{l}\text { Dengan cara membuat atau } \\
\text { mermperbaharui blower agar } \\
\text { aktif kembali }\end{array}$ \\
\hline
\end{tabular}


Tabel 7. Tindakan Perbaikan Terhirup Bahan Kimia

\begin{tabular}{|c|c|c|c|c|c|c|}
\hline Faktor & What & Who & Where & When & Why & How \\
\hline \multirow[t]{2}{*}{ Manusia } & $\begin{array}{l}\text { Tidak memahami sifat } \\
\text { dan karakteristik } \\
\text { bahan kimia }\end{array}$ & \multirow[t]{2}{*}{$\begin{array}{l}\text { Praktikar Mahawasiswa } \\
\text { \& seluruh karyawan } \\
\text { laboratorium }\end{array}$} & \multirow[t]{2}{*}{$\begin{array}{l}\text { Gudang } \\
\text { bahan kimia }\end{array}$} & \multirow[t]{2}{*}{$\begin{array}{l}\text { Pada saat } \\
\text { pengambilan } \\
\text { bahan kimia }\end{array}$} & \multirow[t]{2}{*}{$\begin{array}{l}\text { Untuk menghindari } \\
\text { kecelakaan pada } \\
\text { kesalahan } \\
\text { pengambilan bahan } \\
\text { kirnia }\end{array}$} & \multirow[t]{2}{*}{$\begin{array}{l}\text { Dengan cara mengawasi dan } \\
\text { mernberikan pengarahan } \\
\text { terhadap prosedur } \\
\text { pengambilan bahan yang } \\
\text { benar }\end{array}$} \\
\hline & $\begin{array}{l}\text { Kurangnya } \\
\text { pengawasan dari } \\
\text { karyawan laboratorium }\end{array}$ & & & & & \\
\hline \multirow[t]{2}{*}{ Metode } & $\begin{array}{l}\text { Tidak adanya } \\
\text { pengelompokkan } \\
\text { bahan kimia }\end{array}$ & \multirow[t]{2}{*}{$\begin{array}{l}\text { PraktikanMahawasiswa } \\
\text { \& seluruh karyawan } \\
\text { laboratorium }\end{array}$} & \multirow[t]{2}{*}{$\begin{array}{l}\text { Gudang } \\
\text { bahan kirria }\end{array}$} & \multirow[t]{2}{*}{$\begin{array}{l}\text { Pada saat } \\
\text { pengarmbilan } \\
\text { bahan kimia }\end{array}$} & $\begin{array}{l}\text { Agar bahan kimia } \\
\text { terbagi sesuai } \\
\text { kelompok dan } \\
\text { karakteristik masing - } \\
\text { masing }\end{array}$ & $\begin{array}{l}\text { Dengan cara } \\
\text { mengelompokkan bahan } \\
\text { kimia sesuai karakteristik } \\
\text { bahan kimia masing - } \\
\text { masing }\end{array}$ \\
\hline & $\begin{array}{l}\text { Tidak adanya identitas } \\
\text { pada masing-masing } \\
\text { bahan kimia }\end{array}$ & & & & $\begin{array}{l}\text { Agar bahan kirnia } \\
\text { merniliki identitas } \\
\text { berdasarkan lokasi } \\
\text { bahan }\end{array}$ & $\begin{array}{l}\text { Dengan cara memberikan } \\
\text { identitas pada bahan dan } \\
\text { diletakkan sesuai lokasi } \\
\text { bahan }\end{array}$ \\
\hline \multirow[t]{2}{*}{ Lingkungan } & $\begin{array}{l}\text { Lokasi kerja yang } \\
\text { kurnuh dar kotor }\end{array}$ & \multirow[t]{2}{*}{$\begin{array}{l}\text { PraktikanMahawasiswa } \\
\text { \& seluruh karyawan } \\
\text { laboratorium }\end{array}$} & \multirow[t]{2}{*}{$\begin{array}{l}\text { Gudang } \\
\text { bahan kirria }\end{array}$} & \multirow[t]{2}{*}{$\begin{array}{l}\text { Pada saat } \\
\text { pengambilan } \\
\text { bahan kimia }\end{array}$} & $\begin{array}{l}\text { Agar area gudang } \\
\text { telihat lebih bersih dan } \\
\text { rapih }\end{array}$ & $\begin{array}{l}\text { Dengan cara membuat } \\
\text { daftar piket di area gudang }\end{array}$ \\
\hline & $\begin{array}{l}\text { Tata letak bahan yang } \\
\text { berhamburan dan tidak } \\
\text { sesuai pada tempatnya }\end{array}$ & & & & $\begin{array}{l}\text { Agar penataan diarea } \\
\text { gudang lebih tersusun } \\
\text { rapih }\end{array}$ & $\begin{array}{l}\text { Dengan cara menata tata } \\
\text { letak bahan kimia dengan } \\
\text { menggunakan metode } 5 \mathrm{R}\end{array}$ \\
\hline \multicolumn{7}{|c|}{ Tabel 8. Tindakan Perbaikan Kesalahan Pengambilan Bahan Kimia } \\
\hline Faktor & What & Who & Where & When & Why & How \\
\hline \multirow[t]{2}{*}{ Manusia } & $\begin{array}{l}\text { Tidak memahami sifat } \\
\text { dan karakteristik } \\
\text { bahan kimia }\end{array}$ & \multirow[t]{2}{*}{$\begin{array}{l}\text { Praktikan/Mahawasiswa } \\
\text { \& seluruh karyawan } \\
\text { laboratorium }\end{array}$} & \multirow[t]{2}{*}{$\begin{array}{l}\text { Gudang } \\
\text { bahan kimia }\end{array}$} & \multirow[t]{2}{*}{$\begin{array}{l}\text { Pada saat } \\
\text { pengambilan } \\
\text { bahan kimia }\end{array}$} & \multirow[t]{2}{*}{$\begin{array}{l}\text { Untuk menghindari } \\
\text { kecelakaan pada } \\
\text { kesalahan } \\
\text { pengambilan bahan } \\
\text { kimia }\end{array}$} & \multirow[t]{2}{*}{$\begin{array}{l}\text { Dengan cara mengawasi dan } \\
\text { memberikan pengarahan } \\
\text { terhadap prosedur } \\
\text { pengambilan bahan yang } \\
\text { benar }\end{array}$} \\
\hline & $\begin{array}{l}\text { Kurangnya } \\
\text { pengawasan dari } \\
\text { karyawan laboratorium }\end{array}$ & & & & & \\
\hline \multirow[t]{2}{*}{ Metode } & $\begin{array}{l}\text { Tidak adanya } \\
\text { pengelompokkan } \\
\text { bahan kimia }\end{array}$ & \multirow[t]{2}{*}{$\begin{array}{l}\text { Praktikan/Mahawasiswa } \\
\text { \& seluruh karyawan } \\
\text { laboratorium }\end{array}$} & \multirow[t]{2}{*}{$\begin{array}{l}\text { Gudang } \\
\text { bahan kimia }\end{array}$} & \multirow[t]{2}{*}{$\begin{array}{l}\text { Pada saat } \\
\text { pengambilan } \\
\text { bahan kimia }\end{array}$} & $\begin{array}{l}\text { Agar bahan kimia } \\
\text { terbagi sesuai } \\
\text { kelompok dan } \\
\text { karakteristik masing - } \\
\text { masing }\end{array}$ & $\begin{array}{l}\text { Dengan cara } \\
\text { mengelompokkan bahan } \\
\text { kimia sesuai karakteristik } \\
\text { bahan kimiamasing - } \\
\text { masing }\end{array}$ \\
\hline & $\begin{array}{l}\text { Tidak adanya identitas } \\
\text { pada masing-masing } \\
\text { bahan kimia }\end{array}$ & & & & $\begin{array}{l}\text { Agar bahan kimia } \\
\text { memiliki identitas } \\
\text { berdasarkan lokasi } \\
\text { bahan }\end{array}$ & $\begin{array}{l}\text { Dengan cara memberikan } \\
\text { identitas padabahan dan } \\
\text { diletakkan sesuai lokasi } \\
\text { bahan }\end{array}$ \\
\hline \multirow[t]{2}{*}{ Lingkungan } & $\begin{array}{l}\text { Lokasi kerjayang } \\
\text { kumuh dan kotor }\end{array}$ & \multirow[t]{2}{*}{$\begin{array}{l}\text { Praktikan/Mahawasiswa } \\
\text { \& seluruh karyawan } \\
\text { laboratorium }\end{array}$} & \multirow[t]{2}{*}{$\begin{array}{l}\text { Gudang } \\
\text { bahan kimia }\end{array}$} & \multirow[t]{2}{*}{$\begin{array}{l}\text { Pada saat } \\
\text { pengambilan } \\
\text { bahan kimia }\end{array}$} & $\begin{array}{l}\text { Agar area gudang } \\
\text { telihat lebih bersih dan } \\
\text { rapih }\end{array}$ & $\begin{array}{l}\text { Dengan cara membuat } \\
\text { daftar piket di area gudang }\end{array}$ \\
\hline & $\begin{array}{l}\text { Tata letak bahan yang } \\
\text { berhamburan dan tidak } \\
\text { sesuai pada tempatnya }\end{array}$ & & & & $\begin{array}{l}\text { Agar penataan diarea } \\
\text { gudanglebih tersusun } \\
\text { rapih }\end{array}$ & $\begin{array}{l}\text { Dengan cara menata tata } \\
\text { letak bahan kimia dengan } \\
\text { menggunakan metode } 5 \mathrm{R}\end{array}$ \\
\hline
\end{tabular}

\section{Rekomendasi Perbaikan Identifikasi Bahaya}

Tabel 9. Rekomendasi Perbaikan Hazard

\begin{tabular}{|c|c|c|c|}
\hline $\begin{array}{l}\text { Lokasi } \\
\text { Bahaya }\end{array}$ & $\begin{array}{c}\text { Hazard } \\
\text { Accident }\end{array}$ & Level & Rekomendasi \\
\hline \multirow[t]{5}{*}{\begin{tabular}{l|} 
Gudang \\
Bahan Kimia
\end{tabular}} & Ketumpahan & Extreme Risk & Teknis : Penataan tata letak berdasarkan $5 \mathrm{R}$ APD : Penggunaan jas laboratorium \\
\hline & $\begin{array}{l}\text { Terpeleset } \\
\text { bahan kimia }\end{array}$ & Extreme Risk & $\begin{array}{l}\text { Teknis : Memastikan lingkungan bersih dari bahan yang berhamburan, APD : Penggunaan shoes } \\
\text { safety }\end{array}$ \\
\hline & $\begin{array}{l}\text { Tertelan atau } \\
\text { terhirup }\end{array}$ & Extreme Risk & Teknis : Memastikan sirkulasi udara tidak berbahaya APD : Penggunaan masker atau respirator \\
\hline & $\begin{array}{l}\text { Tersandung } \\
\text { bahan kimia }\end{array}$ & Extreme Risk & Teknis : Penataan tata letak berdasarkan $5 \mathrm{R}$, APD : Penggunaan shoes safety \\
\hline & $\begin{array}{l}\text { Lingkungan } \\
\text { gudang } \\
\text { berbahaya }\end{array}$ & Extreme Risk & $\begin{array}{l}\text { Teknis : Memastikan lingkungan aman dari gas berbahaya, APD : Penggunaan masker atau } \\
\text { respirator }\end{array}$ \\
\hline \multirow[t]{3}{*}{ Laboratorium } & $\begin{array}{l}\text { Bahan mudah } \\
\text { terbakar }\end{array}$ & Extreme Risk & $\begin{array}{l}\text { Teknis : Memastikan bahan kimiajauh dari sumber api, APD : Penggunaan kaos tangan, wear pack, } \\
\text { dan sepatu }\end{array}$ \\
\hline & $\begin{array}{l}\text { Tertelan atau } \\
\text { terhirup bahan } \\
\text { kimia pada } \\
\text { saat praktikum }\end{array}$ & Extreme Risk & $\begin{array}{l}\text { Teknis: Memastikan larutan yang telah dibuat tertutup rapat dalam labu ukur, APD : Penggunaan } \\
\text { masker atau respirator }\end{array}$ \\
\hline & $\begin{array}{l}\text { Tersiram } \\
\text { larutan kimia }\end{array}$ & Extreme Risk & $\begin{array}{l}\text { Teknis : berhati - hati pada pelaksanaan praktikum dan memastikan penggun aan APD tahan bahan } \\
\text { kimia APD : Penggunaan jas laboratorium }\end{array}$ \\
\hline
\end{tabular}




\section{Kesimpulan}

Kesimpulan yang dapat diperoleh dari penelitian:

1. Terdapat perubahan yang sangat signifikan yaitu nilai indeks evaluasi program 5R pada gudang bahan kimia Lab.MIPA sebesar 20 $\%$ dan setelah perbaikan sebesar $75,6 \%$.

2. Dari hasil identifikasi terdapat 23 bahaya resiko dari 7 proses kegiatan. Kontrol resiko dimulai dari bahaya yang mempunyai resiko tinggi kemudian yang lebih rendah tingkat bahayanya sehingga prosesnya menjadi aman.

\section{Daftar Pustaka}

Asmoko, H. \& Ikan, D.T., (2004). Teknik Ilustrasi Masalah - Fishbone diagram. pp.1-8.

Abyadl, Qulubul (2017) Perbaikan Tata Letak Gudang Penyimpanan Dengan Mengunakan Metode Dedicated Storage ( Studi Kasus : PT. Eterindo Nusa Graha). Other thesis, University of Muhammadiyah Malang. 6-8.

Fran et al. (2013). Identifikasi Bahaya, Pengendalian Resiko Dan Keselamatan Kerja Pada Bagian Bengkel Repair Galangan Kapal

International Labour Office, (2013), Keselamatan dan Kesehatan Kerja di Tempat Kerja: Saranan untuk Produktivitas, Modul 5, available at: www.ilo.org/ publns.

Jeffrey K. Liker, (2006). The Toyota Way, Terjemahan oleh Gina Gani, S.T., M.B.A. \& Bob Sabran, S.T., M.M, Jakarta: PT Erlangga.

Liker, J. K. (2006), The Toyota Way, Penerbit Erlangga, Jakarta.

Modul SMK SMTI Bandar Lampung. Menerapkan Kesehatan, Keselamatan Kerja, dan
3. Pengendalian resiko yang diusulkan menggunakan Fishbone ada 3 jenis: ketumpahan bahan kimia, terhirup bahan kimia dan kesalahan pengambilan bahan kimia.

4. Perbandingan data kecelakaan kerja pada sebelum penerapan 5R yaitu tahun 2015, 2016, 2017, dan 2018 sekitar 50 kejadian, setelah penerapan 5R kecelakaan kerja dari bulan Mei September 2019 adalah 0 kecelakaan kerja.

Dengan Menggunakan Metode Job Safety Analysis (JSA) Di Pt Janata Marina Indah, Semarang. Identifikasi Bahaya Pengendalian Resiko.3-5.

Gasperz, V. (2012). Production and Inventory Management. Bogor: Vinchristo Publication.

Indradewi,Laily (2018). Perencanaan

Program K3 (Keselamatan

Kesehatan Kerja) Untuk

Perusahaan Milkindo Dalam

Pemilihan Metode JSA (Job Safety Analysis) (studi kasus : CV. Milkindo berkah abadi)University of Muhammadiyah Malang. 2023,35-38.

Lingkungan Hidup (K3LH), hal 10-25.

Nugraha, A.S., Desrianty, A., \& Irianti, L. (2015). Usulan Perbaikan Berdasarkan Metode 5S (Seiri, Seiton, Seiso, Seiketsu, Shitsuke) untuk Area Kerja Lantai Produksi di PT. X. Reka Integra: Jurnal Online Institut Teknologi Nasional, 3(4), 219-229.

Osada, T. (2014). Sikap Kerja 5S. Jakarta: PPM.

Ramli, Soethman.(2010). Sistem Manajemen Keselamatan dan Kesehatan Kerja. 
Ratnasari, Septa. (2009). Analisis risiko, FKMUI.

Riyadina, Woro, 2008, Cedera Akibat Kerja pada Pekerja Industri di Kawasan Industri Pulo Gadung Jakarta, Jurnal Kedokteran.

Sudrajat et al. (2017). Analisis Potensi Bahaya Dengan Metode Checklist dan What-If Analysis Pada Saat Commissioning Plant N83 Di PT. Gas Industri. politeknik perkapalan negeri Surabaya 60111. ISSN :No.2581-1770. 2-3.

Supriyadi et al. (2015). Identifikasi Bahaya Dan Penilaian Risiko K3 Pada Tindakan Perawatan \& Perbaikan Menggunakan Metode HIRARC (Hazard Identification And Risk Assesment Risk Control) Pada Pt. X. Seminar Nasional Riset Terapan. ISBN: 978-60273672-0-3.2-3.

Suwarni, Putri Endah (2019), Pengaruh Implementasi Program 5S Untuk Meningkatkan Produktivitas di UMKM JBMS Food Kabupaten Pesawaran. Jurnal Industrika Vol. 2 No. 2.

Suwondo, Chandra. (2012). Penerapan Budaya Kerja Unggulan 5S (Seiri, Seiton, Seiso, Seiketsu, Dan Shitsuke) Di Indonesia. Jurnal Magister Manajemen. Vol 1 No 1. 33.

Tanner, John P., Manufacturing Engineering: An Introduction to the basic function.(2nd $\mathrm{Ed}$ ). Florida: CRC Press, 1990.

Wahyudi B., Agung. Identifikasi Bahaya . Bab 2 - (1-17).

Waluyo, Prihadi. (2011). Analisis Penerapan Program K3/5R Di Pt $X$ Dengan Pendekatan Standar OHSAS 18001 Dan Statistik Tes U Mann-Whitney Serta Pengaruhnya Pada Produktivitas Karyawan. Jurnal Standarisasi. Vol 13. No 3. 194-200.

Warman, J. (2012). Manajemen
Pergudangan. Pustaka Sinar Harapan,Jakarta.

Wignjosoebroto, S. (2009). Tata Letak Pabrik dan Pemindahan Bahan. Edisi ketiga. Penerbit: Widya Guna, Surbaya.

Wulandari, Ayu (2015). Penerapan Metode HIRARC Pada Proyek Wika Tower Jakarta Timur PT. WIJAYA KARYA (PERSERO) tbk. Laporan Magang UIN Syarif Hidayatullah JAKARTA 66-89 